\title{
The Anatomy of Police Legitimacy: Dialogue, Power and Procedural Justice
}

\section{Richard Martin}

Bonavero Institute of Human Rights, Faculty of Law, University of Oxford.

\section{Ben Bradford}

Jill Dando Institute of Security and Crime Science, University College London

In a series of influential papers, Anthony Bottoms and Justice Tankebe (2012, 2013, 2017) make the case for a 'dialogic model' of police legitimacy, wherein legitimacy is envisaged as emergent in a process through which the police, as power-holders, make claims to authority which are, in turn, responded to by audiences. Our aim in this article is to analyse this model. We argue that while it has the potential to direct legitimacy research along paths hitherto poorly explored, there is a need for conceptual refinement and development in three key respects. First, through recognition of micro- and meso- levels of legitimation. Second, acknowledgment that police claims-making is contingent on the authorization and endorsement of other actors. Third, a fuller consideration of the qualified role of dialogue - i.e. communication between police and policed - in public audiences' legitimacy assessments. In the spirit of critical engagement and conceptual exploration, this article develops these three insights to propose a modified version of the dialogic model.

Keywords: legitimacy, dialogue, policing, power, procedural justice.

\section{Introduction}

The concept of legitimacy once lay on the margins of criminology, despite it being 'intimately and practically implicated in every aspect of penal relations' (Sparks, 1994: 16). The last two decades, however, have witnessed a 'legitimacy turn' within criminology generally and policing particularly (Tankebe, 2014: 238). A host of quantitative studies (Tyler 2017), including continent wide surveys of public perceptions of criminal justice institutions in Europe (Hough et al, 2013), Africa (Boateng, 2018) and Asia (Boateng and Buckner, 2017) focus on legitimacy or some close correlate, and sit alongside local in-depth qualitative studies (Harkin, 2015) and a number of edited volumes (Tankebe and Liebling, 2013; Mesko and Tankebe, 2015). Collectively, this corpus offers an unprecedented understanding of normative compliance with criminal justice actors and institutions. Its genesis lies in the pathbreaking work of Tom Tyler, who, along with colleagues, has for over three decades examined the core question of why people comply with the law and legal authorities. The legitimacy of the police and wider criminal justice system is an important predictor of people's attitudes toward authority, the law (Tyler, 2006) and even their offending behaviour (Walter and Bolger 2018).

With legitimacy 'now an established concept in criminological analysis' (Liebling and Tankebe, 2013: 1), the last five years have witnessed a determined effort to critically examine just how this concept is used, by whom, and why. Part of this stock-taking has been methodological, involving consideration of how legitimacy is constructed as a variable (Jackson, 2018; Jackson and Bradford 2019) and what insights might be gleaned from a more qualitative appraisal of the dynamics of legitimacy (Harkin, 2015). But theoretical fissures are surfacing too. Bosworth (2013: 510) has asked just how applicable legitimacy, as seen through the lens of procedural justice, really is in diverse, mobile societies. Loader and Sparks (2013: 110), meanwhile, critique the placeless,

\footnotetext{
${ }^{*}$ We are grateful to the three reviewers and editors of Theoretical Criminology for their constructive feedback on earlier drafts of this article.
} 
timeless quality in much procedural justice research, which brackets off a 'series of legal, constitutional, philosophical and political problems' that 'form the contextual and comparative aspects of the criminal question'.

At the forefront of this critical reflection has been Anthony Bottoms and Justice Tankebe's $(2012,2013,2017)$ development of a 'dialogic' model of legitimacy. Arguing that greater attention should be paid to the role and perspective of the police as 'powerholders' in the social relationships through which legitimacy is built and sustained, Bottoms and Tankebe (2012: 129; 2013: 66) propose a 'dialogic and relational' conceptualization of legitimacy, which emphasizes its 'interactive character'. Powerholders make claims to legitimate authority, which are responded to by one or more audiences, and this response may motivate power-holders to re-adjust their claims. The model's appeal is evidenced in its adoption as a conceptual framework for a variety of empirical studies, including in Israel (Jonathan-Zamir and Harpaz, 2014), the USA (Lowrey-Kinberg and Buker, 2017) and the UK (Robinson, Burke and Millings, 2017).

Given this model's growing influence and appeal, our aim in this article to take a step back to pursue a more sustained, critical appraisal. By adopting a theoretical analysis which we think has been largely missing from debates thus far, our aim is not to deny the obvious virtues of the model but rather to further flesh out the conceptual 'anatomy' of legitimacy. We argue there is much value in returning to, and seeking to incorporate, some significant insights contained within the impressive corpus of policing scholarship, alongside illuminating concepts originating from political science. Doing so leads us to argue that while the dialogic model has the potential to direct legitimacy research along paths poorly explored at present - indeed this process is already underway - at this early stage there is need for both conceptual refinement and development across three core dimensions of the dialogic model. These three dimensions provide the structure of this article's inquiry.

First, we propose that a meaningful distinction can and should be made between the micro- and meso- level of legitimation, in order to better account for the form and frequency of legitimacy claims made by individual officers compared with police organizations as collective actors. Second, we argue that what is absent in Bottoms and Tankebe's analysis is the power relationships that connect, indeed bind, different power-holders across society and how these power dynamics might substantially impact upon the production, content and cultivation of the legitimacy claims made by police. Drawing on the work of Berger and Zeldtich, we suggest that the police, as an institution, need the 'authorisation' of other power-holders in order to proceed to seek 'endorsement' from a broader audience, such as the public. Third, we query the idea that claims made by police, that emerge in a dialogue with the policed, are central in determining legitimacy. Drawing on policing research, we suggest this aspect of the model needs to qualified by the fact public assessments of police legitimacy are often based on perceptions and understandings which extend far beyond the behaviour of police officers and organizations.

\section{A 'dialogic' model of police legitimacy}

Police legitimacy has tended to be understood through the lens of procedural justice theory (PJT). On this account, legitimacy is a property possessed by an authority that leads people to believe that the authority and its decisions are right, proper and ought to be deferred to voluntarily, and the basis for these beliefs can be found most importantly in perceptions and assessments of process fairness (Tyler, 2006). According to PJT, normative compliance with an authority is based on a positive and intentional belief about the right of that authority to power, and the key mechanism for this is the internalization of the value that it is morally appropriate, indeed imperative, to obey the dictates of normatively appropriate power-holders (Tyler and Jackson, 2013). The 
central lines of inquiry pursued by criminologists have focused on the antecedents of public perceptions of legitimacy; the outcomes of legitimacy, notably compliance with the law and cooperation with authorities (see Walter and Bolger, 2018); and the drivers of legitimacy for particular social groups (Bradford et al, 2014; Wolfe et al. 2016; Madon et al, 2017).

Bottoms and Tankebe's (2012; 2013, 2017) 'dialogic' model offers the most developed, and increasingly popular, theoretical extension of legitimacy within criminology, born out of its authors' concern that criminologists were focusing too exclusively on the public as the subject of inquiry. In an effort to make a 'fuller account' of how the concept of legitimacy might be 'optimally theorized', Bottoms and Tankebe (2012: 123) reach into political theory. Both Weber (1968) and Raz (2009) argue that authorities are actively engaged in a process of securing their own legitimacy, and in making claims about the moral justifiability of their own power. Successful attempts by rulers to justify their power fosters normative obligation to obey, making legitimacy distinct from naked power or de facto authority. The consequence of this 'Weber-Raz view' - that power-holders actively seek recognition of their right to rule (see also Barker, 2006) - is, according to Bottoms and Tankebe (2013; 60), a 'dialogic and relational' model of legitimacy: power-holders make claims to exercise legitimate authority, which are responded to by one or more audiences which, in turn, may motivate the power-holder to adjust their claims accordingly (see Figure 1). This model is not merely a heuristic device but described as an empirical phenomenon capable of being found in practice. Bottoms and Tankebe (2013: 66) insist that 'social-scientific analyses of legitimacy need to stay close to the empirical realities of claims and responses in specific social contexts.' (see also Bottoms and Tankebe, 2012: 160).

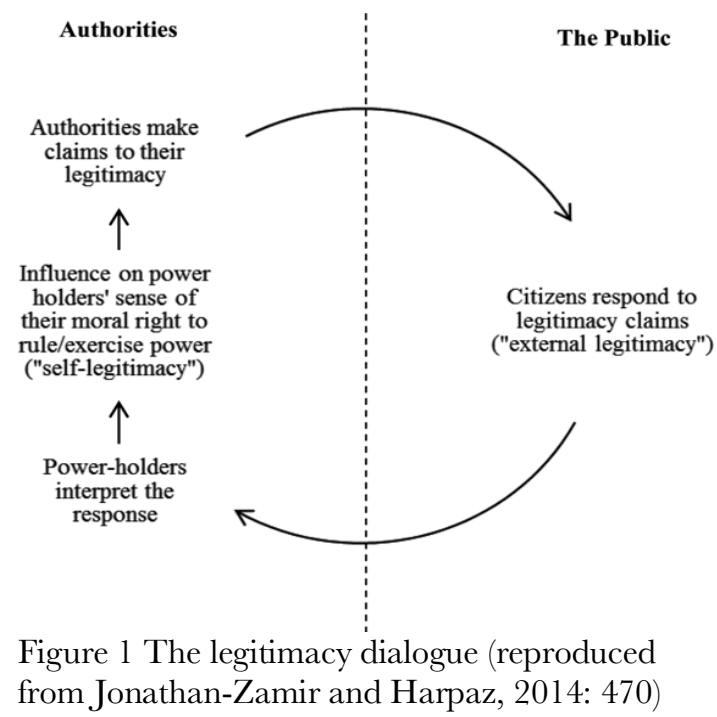

This model has been well received by researchers exploring police legitimacy across jurisdictions, including the UK, the USA, Israel and Australia. Loader and Sparks (2013: 114) acknowledge more work must be done to flesh out how the model connects to political questions, but praise Bottoms and Tankebe's injection of political and social theory into the criminological discussion of legitimacy as 'an enormous virtue'. Tyler and Jackson (2013: 94) endorse the fuller account of legitimacy if offers, stating it 'certainly makes sense to study legitimacy over time as a dynamic interaction among power-holders and subordinates'. Beetham (2013: 25) acknowledges how the dialogic model helpfully 'serves to highlight sites or moments of interaction which may bring about changes in power-holders' perceptions of their own legitimacy'. A number of studies have interpreted the dialogic model in a literal sense. Mazerolle et al (2013: 14, 
22) speak of 'procedurally just "dialogue" during frontline police-citizen encounters' and 'legitimacy enhancing dialogue in procedural justice interventions.' (see also Neyroud and Sherman 2013). Lowrey-Kinberg and Buker (2017) have used it as the conceptual framework around which to hang their discourse analysis of a transcript of a heated conversation between a state trooper and a young African American woman. So too has the dialogic model been used as the basis for quantitative studies exploring the iterative nature of police officers' self-legitimacy (Jonathan-Zamir and Harpaz, 2014).

The incorporation of the perspectives, motivations and actions of power holders into the formulation of legitimacy rightly prompts us to think more carefully and critically about the quality and character of claims made by police to which public audiences respond. But in exploring this dialogic model, and applying it to our respective fields of empirical inquiry alongside the existing corpus of work on policing, we have identified three significant analytical components that we think must be more fully accounted for, and meaningfully incorporated into, the model if it is to fulfil its potential. These are: the distinction between micro/meso levels of legitimation; the contingent nature of claim-making; and the qualified role of police-centred 'dialogue' in public audiences' legitimacy assessments. In the discussion below, we draw heavily on existing work within criminology, insights from which go far in explaining and evidencing each of these three dimensions.

\section{Levels of legitimation: the officer and the organisation}

Bottoms and Tankebe stress the importance of not limiting the inquiry to 'senior' or 'high-level' power-holders, as the tendency has been in political science. Rather, particular attention should be paid to 'more junior power-holders' (Bottoms and Tankebe, 2012: 161), especially in the context of policing given officers' extensive powers, as well as the importance of procedural fairness in their everyday interactions with the public. The 'senior/junior' level distinction is not explored in any great detail by Bottoms and Tankebe and is only hinted at in other studies (Lee and McGovern, 2013; Harkin, 2015). It is here that a helpful distinction can be made between microand meso-levels of inquiry. As long recognised by sociologists, each level is best understood in the particular social context which it is used to make sense of (Mouzelis, 1993). The micro-level can to be taken as concerned with individual officers, specifically their routine encounters with members of the public. The meso-level of inquiry is directed towards the activities of police organizations as corporate actors and their interactions with organizations (power-holders) within and beyond the criminal justice system. This is, of course, just one way of conceptualising the social realities of policing, but these levels of analysis do, we think, provide a helpful platform for fleshing out a fuller, and more precise, account of the nature and forms of legitimacy claim-making. Let us take each level in turn, illustrating the conceptual distinction and its significance using specific examples from the policing scholarship.

\section{The micro-level of the officer}

Bottoms and Tankebe (2012: 154) reason that because frontline officers have more routine and direct interaction than their seniors with members of the public who may challenge or reject police authority, 'it seems likely like that front-line officers might invest a good deal of energy, time, and attention in cultivating and confirming to themselves the moral validity of their positions and authority'. They acknowledge this is a working hypothesis yet to be empirically tested (2012: 153), but based on this premise they state that legitimacy research ought to examine how front-line officers reach their self-beliefs, the content of such beliefs and their consequences for how policing is conducted (Bottoms and Tankebe, 2012: 162-3). What form might this 
cultivation and confirmation of self-legitimacy (i.e. claim-making) take, though? And how might it be researched at the micro-level of individual officers?

Even assuming that challenges to, or at least questioning of, legitimacy do take place on a relatively frequent basis - a claim that remains open to debate - we remain sceptical that officers respond though articulation of what Bottoms and Tankebe (2012: 154) describe as 'the moral validity of their positions and authority'. To be sure, by way of their actions, expressions and general demeanour, officers can communicate that they are acting fairly and properly, are trustworthy, and that those who they are dealing with are worthy of respect and consideration (Bradford et al., 2009: 6); i.e., with procedural justice. This may be considered to be an implicit claim to legitimacy. Moreover, such behaviours can be tactically deployed to extract situational compliance - although the labels procedural justice and legitimacy may seem inappropriate in such circumstances. But the idea that they amount to an explicit claim to normative justifiability, and thus enter into a legitimacy dialogue, seems a little far-fetched.

Consider the example of stop and search. Given that in a democratic society people enjoy the right to go about their lawful business un-interrupted, when police officers intrude, and conduct a stop and search, they are referring to, drawing from or utilising legitimacy, because they are able to do this only on the basis of their special status as police. And stop and search encounters plainly do throw up challenges to legitimacy, as those stopped question the decision-making, motives and even the fundamental right of police to act in this way (Epp et al, 2014). When confronted by such challenges, though, how often do front line officers really delve into the deeper realm of moral justifications of power? In responding to a challenge to their right to conduct a stop/search, they may rely upon implicit understandings of their role, or an inner voice', to explain what they are doing (a point we return to below). But it seems doubtful that foundational questions of authority will be consciously articulated in often fleeting and sometimes fraught interactions with members of the public. When challenged by the individual who they have stopped, the officer may well explain why this has occurred - because they suspected the individual had committed an offence, or there was a risk of violent crime in the area, perhaps even proceeding to assert that 'I have the right to exercise this power because it is granted to me under Section 1 of the Police and Criminal Evidence Act 1984'. This may amount to an implicit claim to legitimacy on the basis of legality. But it might equally be described as an assertion of legitimate authority presumed to be present, rather than a claim to legitimacy constituted by the expression of shared values: the latter necessitates a normative explanation by the officer that is absent in any presumption of the legitimate power to act. Should the challenge continue, of course, the response is likely to be escalation towards, and into, various levels of force to assert the officer's will that the stop/search will in fact go ahead. What here amounts to a substantive, discursive, 'claim' to legitimacy?

The notion of claims-making inherent in the dialogic model is rendered problematic by consideration of the way police officers often behave in 'real life' situations, perhaps particularly when challenged. They do not seek to demonstrate their legitimacy - to justify their ability to demand obedience - but to obtain obedience, by force if necessary but much more frequently by a variety of tactical statements and actions. It seems more appropriate to argue that police draw on their own sense of legitimacy to enable action, rather than use actions - and words - to purposefully demonstrate to an audience that they are acting in morally justifiable ways. As Bittner (1974: 30) suggests, the officer is not only empowered but expected by the public and colleagues to impose a provisional solution through decisive action to 'something-thatought-not-to-be-happening-and-about-which-someone-had-better-do-something-

now!' In responding to these emergent problems, the police officer, unlike the judge, need not 'entertain motions, nor are they required to stay their orders while the motion receives reasoned consideration.' (Bittner, 1974: 34). Rather, they assert their will, albeit that this may involve persuading or even cajoling the individual or group involved. Crucially, in our experience of observing many hours of police-public 
interactions, officers rarely seek to explain their actions to bystanders, but rather assume that their status as police officers enables them to act in the absence of explanation.

This does not mean that for rank and file police officers external or internal legitimation is either unobservable or irrelevant. It is to acknowledge, contra to Bottoms and Tankebe's (2012: 153) assertion that officers are regularly engaged in legitimacy dialogues, that the behaviour and utterances of officers, particularly in their interactions with the public, are unlikely to readily expose the nature or content of the foundational justifications for their authority. In this regard, Giddens' (1984) distinction between 'practical' and 'discursive' consciousness seems particularly insightful. Individuals have a practical consciousness which 'consists of all the things which actors know tacitly about how to "go on" in the contexts of social life without being able to give them direct discursive expression' (Giddens, 1984: xxiii cited in Carrabine, 2000). The notion of dialogue may thus be ill-suited to the empirical reality of mundane police work and, therefore, the majority of situations in which legitimacy is at stake. Police officers may 'mobilize and interpret discursive understandings' of their own legitimacy, but they likely do so without a 'fully mapped out conception of the structure of each discourse' (Carrabine, 2000: 317).

This ought to encourage us think more critically about how 'micro-level' legitimacy claims-making might be researched. As is apparent from recent research in England and Wales, observational and ethnographic techniques would appear particularly important in detecting the diversity which claims may take based on officers gender, ethnicity and class (Loftus, 2008), but also the distinct roles they perform, from routine uniform policing to community, investigative and covert policing (Loftus, Goold and Giollabhui, 2015). Indeed, Bottoms and Tankebe (2013: 70) concede that acts of selflegitimation 'quite often occur within private contexts' - when officers, for example, return to the relative calm and privacy of the police station. It is within such 'backstage' environments that police 'storytelling' takes place - stories that can serve to protect and enhance the status of the police (Van Hulst, 2013), and through 'which challenges to particular actions are refuted, and in which the moral worth of those actions is reestablished' (Mulcahy, 1994: 416).

\section{The meso-level of the organisation}

The moral justifications of power which lie at the heart of the concept of dialogic legitimacy might, we think, be more clearly devised and articulated at the meso-level. It is here that the status, function and stability of the police, as an institution 'made and imagined' (Loader, 2016: 432), becomes most visible. Police wield significant coercive and symbolic power, mandated as they are with the value laden task of maintaining order in an ever-changing society. This exposes them to, and involves them in, discourses that swirl around crime, justice, security, citizenship, terrorism, austerity, privatisation, and so on. Amongst these institutional arrangements and political conditions, we can tune into what has been described as the 'corporate police voice' (Loader and Mulcahy, 2001). Although individual (often elite) actors remain relevant, it seems to us more parsimonious, and arguably more accurate, to frame this as organizational behaviour that articulates justifications of the police function and status, especially during periods of significant institutional change, uncertainty or crisis.

In England and Wales, McLaughlin and Murji (1998) use the concept of 'storylines' to trace how the Police Federation's challenges to political elites was founded on its ability to 'deploy an important "store" of potent legitimating storylines about the nature of the British police and police work' (McLaughlin and Maurji, 1998: 368). The veracity of these storylines is less relevant than the ideological work they perform in constructing a vision able to "elicit "high" audience responses' from those who were pulling the leavers of power and capable of effecting reform (McLaughlin and Murji, 1998: 397). Likewise, Cote-Lussier's explains how, in a contest over who was to police Montreal's subway, the public police sought to legitimate their status as the city's central security provider. This was achieved through a series of carefully constructed justifications 
'brought forth in a broad narrative of legitimacy (e.g. regarding its expertise and ability to reassure the public), demonstrating an institutional drive to secure police work' which ultimately ousted private security firms from patrolling the subways (CoteLussier, 2013: 184).

Perhaps the closest empirical exploration of legitimacy's dialogic property, and best demonstration of it at the meso-level, remains Mulcahy's (2006) account of the 'legitimation process' that characterised police-community relations during the Northern Irish conflict. The three stages of this process described by Mulcahy - reform, representation, and public response - chime with the claim-response dynamic of Bottom and Tankebe's model. Each stage is 'inextricably linked with the pursuit of normalcy and the naturalization of a particular set of social relations' (Mulcahy, 2006: 15). 'Reform' seeks to address a policing system perceived as dysfunctional (Mulcahy, 2006: 15). 'Representation' is 'the expression and communication of particular images of policing by the police (or other agencies seeking to enhance police legitimacy)' (Mulcahy, 2006: 17). The Royal Ulster Constabulary relied upon careful, strategic development and deployment of 'organisational memories' during the conflict, alongside narratives of 'professionalism', 'consent' and 'service', 'mobilised to maximise the force's positive self-conception, minimise its problems, and side line its critics' (Mulcahy and Ellison, 2001: 286). 'Response' is an 'examination of the nature and effects of public reactions to police reform and representational strategies', in particular 'the dynamic between the police and the policed' (Mulcahy, 2006: 19).

These empirical studies reveal how police legitimation at the meso-level can force to the surface the 'high order principles at stake in arguments' (Cote-Lussier, 2013: 184), illuminating the police function and its relationship with other public and private actors. So too has the emergence of social media provided new forums for hosting legitimating 'storylines'. Scholarship over the last decade has evidenced how the police attentively, and at times anxiously, seek to cultivate, manage and defend a corporate 'reputation' or 'brand' though professionalised and centralised public relations and media units - an enterprise undoubtedly bound up with the wider project of institutional legitimation. Empirical research in the UK (Mawby, 2010) and Australia (Lee and McGovern, 2013) on police media units, for instance, has found the concept of legitimacy to be 'central to understand(ing) the motivations of police media work and some of the themes through which respondents describe their work' (Lee and McGovern, 2013: 107).

Bottoms and Tankebe's (2012: 153) scepticism about Barker's claim that legitimation efforts are made with greater time, attention, energy and intensity at the core of an organisation (Barker, 2001: 71) thus seems curious. They perhaps underacknowledge the empirical studies that reveal the great energy and purpose that goes into engineering legitimacy claims at the 'centres' of police organizations. But beyond this, the very distinction between meso-and micro levels of inquiry - similarly observed by Carrabine (2000) in the prisons context - is a conceptual clarifier worth making because we suspect there is likely to be notable variation in the selection, substance and function of the claims being made and, relatedly, the audiences at which they are directed. When examined alongside one another, these variations may offer crucial insights into how organisational reforms and 'visions' used to legitimate policing, expressed through the corporate voice of senior officers or public relations teams, interact with, and are mediated by, legal regulation, institutional arrangements, occupational culture and working practices. Such an approach does not necessitate prioritising one level of inquiry over the other - what Carrabine (2001: 313) refers to as the problem of 'asymmetry' - but rather underscores the importance of critically examining both, using the notion of self-legitimation as a dual dimension within a dialogic conceptualisation of legitimacy.

\section{Powerful audiences and the contingency of legitimacy}


Bottoms and Tankebe (2013: 65; 2017: 73-4) stress that 'many claims to legitimacy are being made by... many different actors, often to different audiences' and that 'there can be many different dialogues happening simultaneously.' Yet, despite their aim to move beyond procedural justice, aside from their brief reference to the need for local police chiefs 'to legitimate themselves upwards (to state or national governing bodies)' (Bottoms and Tankebe, 2013: 65), the overwhelming emphasis of their analysis remains on the public as the principal, and seemingly most important, audience for police legitimacy claims. Research adopting the dialogic model remains similarly directed at the public as the audience for legitimacy claims (e.g. Jonathan-Zamir and Harpaz, 2014; Harkin, 2015), while Beetham (2013: 26) has stated 'in nation states it is the citizens who constitute the ultimate audience for, and judge of, legitimacy claims.' Yet even in liberal democracies, where the public is obviously an important audience - we expect public institutions to be interested in and receptive to assessments of power wielded in our name - it is not the only one. As suggested by Loader and Sparks, (2013: 110), police power is implicated in the 'legitimacy of a range of governing authorities in responding to problems of order and security' (our emphasis).

What is absent in Bottoms and Tankebe's analysis is the power relationships that connect, indeed bind, different power-holders and how these dynamics might affect the production, content and cultivation of the legitimacy claims made by organisational actors. Policing scholarship has continued to document that claims to legitimacy are often directed at a complex constituency of powerful actors and elites, including politicians (see Loader and Mulcahy, 2001 in England; Murray and Harkin 2016 in Scotland), oversight bodies (see Campau, 2015 in the Canadian context), the media (see Lee and McGovern, 2013 in the Australian context) and professional organisations (e.g. the College of Policing in England and Wales). Developing this further, other powerful institutions in society are not simply audience members being addressed in a legitimacy dialogue, but constitutive of the power held by police organisations, and in turn, of the claims they are capable of plausibly cultivating. A collection of elite actors, and other state and private organizations, thus play an active, even determinative, role in the legitimation process. Indeed, organizations cannot exercise authority, or indeed wield naked power, without the support and assistance of other power-holders. This has been demonstrated in its most malign form in the UK by various high-profile scandals, such as institutional sexual abuse, off-shore tax schemes and the Hillsborough football disaster, where wrong-doing (i.e. power exercised for inappropriate ends) by one organization was concealed, and thus enabled, by the actions or inactions of others.

It is necessary, therefore, for the dialogic model to account for the fact that legitimation processes always rely at least in part on other actors, organizations and institutions. Here there is much to be found in the theoretical insights of Berger and Zelditch (1998), who offer an account of legitimacy as embedded within social networks that facilitate, mediate and limit the actions of power-holders: the 'exercise of authority is actually a matter of the coordinated action of a system of actors, not a dyadic relation between a superior and subordinate' (chapter 12: 1998). Identifying structures and hierarchies of power, they make a distinction between two levels of support for authorities that affect the relationship between power-holders and subordinates: first, from peers or superiors of the authority (which they label authorisation); and second, from the peers of those subject to it (which they describe as endorsement). For a directive to be executed legitimately it must be authorised by other power-holders, and endorsed by the peer-group of the individual or group over whom it is exercised. This leads Berger and Zelditch (1998: 269) to argue that '[1] egitimacy will normatively regulate power if, and only if, it is true that others will not back invalid directives. Thus, the normative regulation of powers lies in the ... authorization and endorsement by a complex system of others.' Powerful actors are not simply another audience member that a power-holder appeals to, but an integral part of the latter's very ability to assert (and even substantiate) a claim to legitimacy. 
Introducing the role of peers, superiors and elites to our understanding of legitimacy does not necessarily contradict Bottoms and Tankebe's dialogic model, but rather extends it by illuminating the conditional nature of legitimacy - something which is peripheral in their analysis. Berger and Zelditch's conceptualisation of legitimacy makes clear that other powerful social, political and economic actors are not simply members of 'the audience' that power-holders appeal to, but are, in fact, a key component of the processes through which they are able to assert and substantiate a claim to legitimacy in the first place. There is not simply power-holders and audiences, but a more complex division of labour of authority itself, in which 'any authority A is accountable to others [peers or superiors] for exercise of that authority over B' (Berger and Zelditch, 1998: xx). It is readily apparent how this might apply to police practice. In order to carry out fundamental aspects of their work - activities often intimately connected with the application of power - the police need 'authorization' from other actors, both informally, such as community representatives, and formally, through the legislature and judiciary.

The interdependence of meso-level networks in the generation and reproduction of legitimacy is illustrated by Martin's research on the construction and deployment of human rights claim-making by the Police Service of Northern Ireland (PSNI) after its landmark reform following the 1998 peace settlement. Martin reveals how the police oversight body, the Northern Ireland Policing Board, evidenced and endorsed the PSNI's bold rights claims (expressed in the language of objectivity, legality and accountability) through the high-profile speeches, formal reports and newspaper articles of the Board's chairpersons and legal advisors. The Board invested its reputation in its pioneering human rights monitoring programme, heavily branding and promoting itself as a world-class oversight body, attracting a raft of international policy-makers and police reformers to observe its work. The Board bound its own legitimacy to being an effective actor overseeing the PSNI and ensuring human rights compliance, making it receptive to, and keen to promote, the PSNI's claims to accountability and successful reform. The Board's public 'authorisation' of the PSNI's rights claims at a corporate level has enabled the PSNI to assert its narrative of legality and accountability in response to Republican and Loyalist community accusations of 'partisan' policing, as well to enhance its 'brand value' amongst policy-makers from the transnational policing community (Ellison and O'Reilly, 2008).

Legitimation is therefore a process not only contingent on how police claims are received by audiences but also on what is, and is not, possible within relevant institutional and socio-cultural frameworks. In Murray and Harkin's (2016) account of the rise and fall of stop and search in Scotland, for example, senior police, politicians and local media all performed a role in downplaying the contentiousness of search powers and promoting a narrative of the apolitical use of non-statutory stop and search. Despite soaring numbers of stops - and extremely limited evidence of their efficacy in reducing crime - senior officers used the media to convey the police 'spin' on strategies and tactics. This was initially effective, and, citing Steven Lukes' (2005) theory of power, Murray and Harkin illustrate how elite alliances, when bolstered by shared values, can serve to diminish public dissent over what would otherwise be contested issues. Yet, eventually, even this alliance was unable to hold back wider criticism of Police Scotland's stop and search policy and practice, prompting a rapid change of tack and huge reduction in use of the power. So too are there complex networks of local security providers, drawn from the public and private sector, which influence the legitimation process, including local councils, private security firms, residents' groups and housing providers. In crafting compelling claims to legitimacy - via crime control, procedural fairness, distributive justice - the police are dependent upon the power of this plurality of security providers to endorse, and actively contribute to, such claims through the law enforcement and order maintenance services they offer (Brodeur, 2010; Lister and Jones, 2016). 
Developing this analysis of the social context further still, subordinates are attuned not only to the legitimacy claims made by authorities, but also to the extent that these appear mandated by others in their social environment. These 'mandates' may be from local or community 'power-holders', or simply from other individuals and groups with whom people share social and physical space. Antrobus et al. (2015), for example, report that in a sample of Australians respondents' beliefs about whether others in their community trusted and supported the police had an association with their legitimacy judgements distinct from assessments of police performance and behaviour. Holding constant personal assessments of police procedural justice, distributive justice and effectiveness, individuals who believed that others in their community supported and deferred to police were more likely to report a sense of duty to obey police. The fact that their assessments of what others think are likely to be entangled with people's own judgements, feelings and motivations is, in a sense, precisely the point. Whether others 'really do' endorse the police is less important than the perception that this is, indeed, the case.

\section{The subjects of legitimation: forming perceptions of the police}

Thus far we have concentrated on the claims police make to legitimacy, how these might be shaped by wider social and institutional contexts, and the role of powerholders in supporting, or undermining, legitimacy claims. Little that we have said sits definitively outside Bottoms and Tankebe's original model. We might wish to reconsider what constitutes a claim to legitimacy, and how often such claims are made and to whom, but we have no doubt that such claims are made and can be important in a discursive process that establishes and reproduces legitimacy. It is clear, however, that beyond the kind of internal dialogue suggested by Bottoms and Tankebe and described more fully by Barker (2001), the claims made by police must be received and processed by an audience. This audience will always comprise, to a greater or lesser extent, the various publics over which police claim legitimate authority, and it is here that a more stringent test of the dialogic model of legitimacy comes into focus. Put bluntly, the idea that claims made by police are central in determining legitimacy, and that these emerge in a dialogue with the policed, sits uncomfortably with the fact public assessments are often based on perceptions and understandings which extend far beyond the behaviour of police officers and organizations. The dialogic model relies to a significant degree on the metaphor of conversation or at least of discourse - on claim and counter-claim, actor and audience, transmission and reception. Yet when one examines the bases of people's actual legitimacy beliefs, these are at best only partially interlocutionary.

This challenge comes in two inter-connected parts. First, study after study has shown that when making judgements about the legitimacy of the police, or about directly adjacent aspects of police-public relations such as trust or satisfaction, people draw on a wide range of attitudes, orientations, beliefs and experiences. Consider, for example, research that has demonstrated the importance of neighbourhood characteristics and conditions in shaping trust and legitimacy (e.g. Sampson and Bartusch 1998; Jackson et al. 2013). On this account, the objective and particularly subjective quality of local social and physical environments exert an important influence on the way residents think about the police. Neighbourhood disadvantage, (dis)order, social cohesion and collective efficacy are strongly predictive of perceptions of police. While at the margins police may be able to exert some influence on such processes, which could be construed as comprising a claim to legitimacy - for example by leading a 'clean-up campaign' in a physically disorderly neighbourhood - it seems obvious that the primary reasons why some neighbourhoods are more orderly, cohesive and simply richer than others lies well beyond the remit, control and indeed knowledge of the police. Here, legitimacy is in an 
important sense a by-product of other social processes, which bear little relation to the willed or even coincidental outcomes of police activity.

The local is, moreover, intimately linked to national and international processes. The social and geographical marginalization of specific social groups - e.g. ethnic minority and immigrant communities - is associated with group-members' attitudes and orientations toward police independent of direct experiences of policing (Weitzer and Tuch, 2010). Similarly, the change in institutional context associated with immigration has been shown to be correlated with perceptions of police. Immigrants who move from poorer, more corrupt countries where the rules of law is weaker to richer, less corrupt countries where the rule of law is stronger tend to have more favourable views of police in the destination country, compared either with other immigrants or indeed nonimmigrants (Röder and Mühlau, 2012; Bradford and Jackson, 2018), again seemingly independent of direct experiences of policing. In short, 'there are likely to be multiple causes of people's ideas about and actions in relation to the police, encompassing such potentially important predictors as the strength of the democratic process, state legitimacy, and historical-institutional context' (Bradford et al, 2013: 557).

The extent to which police command legitimacy in a particular context is therefore dependent on many factors that do not appear to take the form of a constant - or even occasional - dialogue. In his seminal Politics of the Police (2010), Reiner makes precisely this point. Discussing the attainment of widespread legitimacy by the British police, a process that lasted from the inception of the Metropolitan Police Service in 1829 until well into the $20^{\text {th }}$ century, Reiner argues that the all-important facilitating factor was not any aspect of police policy or practice but the changing social, economic and political context, and in particular the incorporation of the working class as citizens into the political, social and economic institutions of British society (2010: 77). This process of incorporation changed the way ordinary people thought about policing - moving the relationship from one revolving around the coercive application of external norms to a more consent-based understanding of policing based on shared norms - and it did so by altering the structural location of working-class communities, and not necessarily the way police actually interacted with members of those communities.

The second empirical challenge to the notion of the legitimacy 'dialogue' can be introduced by noting the surprising resilience of public opinion in the face of police behaviours that should, in theory, undermine legitimacy. On many accounts, for example, the history of British policing over the last 50 years is one of scandal - the Birmingham six, Guildford four, Brixton riots, the miner's strike, Hillsborough, Stephen Lawrence, 'Spycops' and a host of others - involving police abuse of power, procedural injustice, corruption and so on (see Reiner, 2010, among many more). Yet the police remain one of the more trusted institutions in modern Britain, and certainly retain higher levels of legitimacy (at least as defined here) than, for example, a political class similarly tainted by scandal (Bradford, 2016). This poses a challenge for both the dialogic model of legitimacy and the wider PJT literature that it seeks to extend. Over several decades, some of the most high-profile 'communication' between police and public has conveyed storylines or messages that ought to undermine legitimacy, communicating that police do not behave in ways aligned with norms of probity, transparency, neutrality, respectfulness and trustworthiness. Yet this does not seem to have fatally soured the relationship between police and policed; which is not to say, of course, that public opinion is either static or unchanged over the period (Jackson et al. 2013).

One answer to this apparent conundrum can be found within PJT itself. Lay understandings of policing are heavily influenced by issues of identity, selfcategorization, and belonging. One reason why people care so much about the fairness of police activity is that it is 'identity relevant' to them (Sunshine and Tyler 2003). As has been explored in the UK context in particular, the behaviour of police officers, especially in relation to procedural justice, can transmit messages of inclusion and belonging, or exclusion and denigration, to those with whom they interact (Bradford et 
al. 2014). Police activity is judged against the group norms and expectations indicated by the identities of those observing it, such that police can place themselves into in- or outgroup categories (Radburn and Stott 2018).

Stop and search provides the paradigmatic example of the fact that police-public relations, and the legitimacy dialogues that consist in these relations, are conditioned by in important ways by the identities of those involved; most pertinently, of course, in terms of race and ethnicity (Bowling and Philips, 2007). The way an officer conducts a stop and search encounter maybe received and processed quite differently by the individuals involved, as a result, for example, of historical discrimination at the community level (Owusu-Bempah, 2017), discriminatory experiences at the individual level (is it the first or the tenth time they have been stopped? Is it a traffic safety stop or an investigatory stop? See Epp et al, 2014) and the interaction between the two. Similarly, the meso-level legitimacy claims made by police in relation to stop and search, for example that is an effective and vital crime-fighting tool, might be received and processed quite differently by people across ethnic groups. Indeed, one could argue that the inability to recognise this fact, at individual and organizational levels, is one reason why police have found it so hard to deal with the issues that stop and search seems to continuously raise.

Yet, the link between identity and legitimacy may also go some way to explaining the (arguably) puzzling persistence of legitimacy. Here, the argument is that police represent superordinate forms of identity - nation, community, the 'law-abiding majority' - with which most people identify, and identification with these categories promotes, for a variety of reasons, identification with and therefore legitimation of the police (Bradford 2016). Whether for reasons of basic ingroup solidarity, the need to avoid the cognitive dissonance generated by seeing the authorities of valorised groups as illegitimate and/or to maintain a positive 'unity of impression' of those same authorities, a widespread feeling that police share an identity with the policed seems to 'prop up' legitimacy, providing a reservoir of support (Easton, 1965) against which apparently legitimacy undermining activity can be discounted. This process again appears to fundamentally complicate the idea of dialogue. At certain times and places, group- and identity-dynamics independent of police activity may be as or more important in forming and reproducing legitimacy (or undermining it) as anything the police do or say.

\section{Conclusion}

Over two decades ago, Sparks (1994: 14, 17) described legitimacy as rooted in the 'claims made by any dominant group to justified authority' and the 'inherent dialectical energy' that connects issue of the present to questions of the future. Yet the simple but fundamental insight that power-holders ought to be a central component of how legitimacy is theorised has been largely missing from criminological conceptualisations of legitimacy. Bottom and Tankebe's dialogic model is thus a timely and original contribution in so far as it foregrounds the role of criminal justice agents as powerholders that actively seek to cultivate claims of the morality of their power - claims, which, in turn, can prompt normative compliance amongst public audiences. Our aim in this article has been to introduce three conceptual insights we think are crucial to integrate into this model if it is going to serve as an accurate and meaningful account of how normative compliance with the police is generated by organisations and individual officers, and sustained within communities.

Pulling the three strands of our analysis together, we propose a modified dialogic model which captures, first, the distinction introduced between the micro- and mesolevels of legitimation - the former revolving around the individual officers, the latter around police organisations. Bottoms and Tankebe rightly seek to locate legitimacy within an account of power in society, engaging closely with Weber to draw attention 
to the social hierarchies, power-structures and dominant ideologies that have the power to influence the construction and reception of legitimacy claims. Extending beyond the macro though, variation at meso- and micro-levels of inquiry offer important insights into how organizational reforms and visions used to legitimate policing - expressed through the corporate police voice of senior officers or police public relations teams interact with, and are mediated by, legal regulation, institutional arrangements, and culture and practice on the frontline. Understood in the sociological context of mundane police work, we suggest that police claim-making - explicit claims to normative justifiability of power - is most likely to take place, and articulated most fully and purposefully, at the meso-, rather than micro-, level of inquiry.

Second, and consequently, our modified model accommodates the power relationships that connect, indeed bind, different power-holders, and how these dynamics might condition the production, content and cultivation of legitimacy claims. Drawing on the insights of Berger and Zelditch, we suggest that the police, as an institution, need the 'authorisation' of other power-holders in society in order to proceed to seek 'endorsement' from the broader audience of the 'policed'. Authorisation and endorsement, in turn, influence the legitimacy judgements of individuals subject to police power. Legitimation thus becomes a process contingent not only on how police claims are received but also on what is and is not possible within the institutional frameworks and networks within which they operate. How and why political discourse and hierarchies of power operating at the macro-level level influence, or frame, the legitimacy claims constructed and deployed at the micro- and meso-levels, are, as Loader and Sparks (2013) suggest, questions deserving closer attention in future work.

Third, our modified model steers away from an overly police-centric analysis by accounting for the fact public assessments of legitimacy are often based on perceptions and understandings which extend far beyond the behaviour of police officers and organizations. Unlike our two earlier arguments, this we believe poses a fundamental challenge to the idea of dialogue. A wide range of empirical evidence suggests that social, economic, political and institutional factors shape the legitimacy of this foundational state institution. Much further conceptual and empirical work is needed to disentangle how important these factors are vis a vis the concept of dialogue and, in particular and to return to where we started, procedural justice in the relationship between police and policed. In line with the weight of current evidence, we consider procedural justice, as something police $d o$ and as a justificatory claim, to be central the empirical legitimacy of the police in many contexts. Yet its relative weight in relation to these external factors, and authorization and endorsement by others, remains to be determined, and will likely vary significantly over time and space. A model of legitimacy that does not account for these factors risks obscuring fundamental aspects of the relationship between police and policed.

\section{References}

Antrobus, E., Bradford, B., Murphy, K. and Sargeant, E. (2015). Community norms, procedural justice and the public's perceptions of police legitimacy, fournal of Contemporary Criminal fustice 31(2): 151-170.

Barker, R. (2001) Legitimating Identities: Self-Presentation of Rulers and Subjects (Cambridge: Cambridge University Press).

Beetham, D. (2013) 'Revisiting Legitimacy, Twenty Years On' in in J. Tankebe and A. Liebling (eds.). Legitimacy and Criminal fustice: An International Exploration. (Oxford: Oxford University Press). 
Berger, J. and Zelditch, M. (1998) Status, Power and Legitimacy (New Brunswick, N.J., Transaction).

Boateng, F. (2018) 'Police legitimacy in Africa: a multilevel multinational analysis' Policing and Society 28(9) 1105-1120.

Boateng, F. and Buckner, Z. (2017) 'Police legitimacy in Asia: findings from a multilevel hierarchical non-linear analysis' Policing and Society [published online] 1-18.

Bowling, B. and Phillips, C. (2007) 'Disproportionate and Discriminatory: Reviewing the Evidence on Police Stop and Search' Modern Law Review 70(6) 936-961.

Brodeur, J. (2010) The Policing Web (Oxford: OUP).

Bosworth, M. (2013) 'Book Review: Justice Tankebe and Alison Liebling (eds), 'Legitimacy and Criminal Justice: An International Exploration' Punishment and Society 18(4) 509-512.

Bottoms, A. and Tankebe, J. (2012) Beyond Procedural Justice: A Dialogic Approach to Legitimacy in Criminal Justice. Fournal of Criminal Law and Criminology. (102) 119-170.

Bottoms, A. and Tankebe, J. (2013) 'A Voice Within': Power-Holders' Perspectives On Authority And Legitimacy in J. Tankebe and A. Liebling (eds.). Legitimacy and Criminal Fustice: An International Exploration. (Oxford: Oxford University Press).

Bottoms, A. and Tankebe, J. (2017) 'Police Legitimacy and the Authority of the State' in Bois-Pedain, A., Ulväng M. and Asp, P. (eds) Criminal Law and the Authority of the State (Oxford: Hart Publishing).

Bradford, B. (2016). 'The dog that never quite barked: Social identity and the persistence of police legitimacy', in Bosworth, M., Hoyle, C. and Zedner, L. (eds) Changing Contours of Criminal Fustice: Research, Politics and Policy. Oxford: OUP.

Bradford, B. (2017) Stop and Search and Police Legitimacy. Oxford: Routledge.

Bradford, B. et al. (2014.) 'What price fairness when security is at stake? Police legitimacy in South Africa' Regulation and Governance 8 246-68.

Bradford, B., Jackson, J. and Stanko, B. (2009) 'Contact and confidence: revisiting the impact of public encounters with the police' Policing and Society 19(1) 20-46.

Bradford, B., Topping, J., Martin, R. and Jackson, J. (2018) Can diversity promote trust? Neighbourhood context and trust in the police in Northern Ireland. Policing and Society Advance Access

Campau, H. (2015) "Police Culture" at Work: Making Sense of Police Oversight' British Fournal of Criminology 55(4) 669-687.

Carrabine, E. (2000) 'Discourse, governmentality and translation: Towards a social theory of imprisonment' Theoretical Criminology 4(2) 309-331.

Ellison, G. and O'Reilly, C. (2008) 'Ulster's policing goes global': The police reform process in Northern Ireland and the creation of a global brand' Crime, Law and Social Change 51 331-351. 
Epp, C., Maynard-Moody, S., and Haider-Markel, D. (2014) Pulled over: how police stops define race and citizenship (Chicago: University of Chicago).

Gerth, H. and Mills, C. (1946) From Max Weber: Essays in Sociology (New York: OUP).

Giddens, A. (1984) The Constitution of Society (Cambridge: Polity Press)

Harkin, D. (2015) 'Police legitimacy, ideology and qualitative methods: A critique of procedural justice theory' Criminology and Criminal fustice 15(5) 594-612.

Hough, M. and Jackson, J. and Bradford, B. (2013) 'The Governance of Criminal Justice, Legitimacy and Trust in S. Body-Gendrot et al. (eds) The Routledge Handbook of European Criminology, (Oxford: Routledge).

Jackson, J., Bradford, B., Stanko, E.A. and Hohl, K. (2013). Fust Authority? Public Trust and Police Legitimacy. Oxford: Routledge.

Jackson, J. (2018) 'Norms, Normativity, and the Legitimacy of Justice Institutions: International Perspectives' Annual Review of Law and Social Science 14 145-165.

Jackson, J. and Bradford, B. (2019) Blurring the Distinction Between Empirical and Normative Legitimacy? A Methodological Commentary on 'Police Legitimacy and Citizen Cooperation in China. Asian Fournal of Criminology Online First.

Jonathan-Zamir, T. and Harpaz, A. (2014) 'Police Understanding of the Foundations of their Legitimacy in the Eyes of the Public: The Case of Commanding Officers in the Israel National Police' British Fournal of Criminology 54 469-489.

Kalberg, S. (2002) The Protestant Ethic and the Spirit of Capitalism, Max Weber Los Angeles: Roxbury Publishing Company)

Lee, M. and McGovern, A. (2013) 'Force to sell: policing the image and manufacturing legitimacy in Northern Ireland' Policing and Society 11(3-4) 383-404.

Lister, S. and Jones, T. (2016) Plural Policing and the Challenge of Democratic Accountability. In: Lister, SG and Rowe, M, (eds.) Accountability of Policing. (London: Routledge)

Loader, I. (2016) In Search of Civic Policing: Recasting the 'Peelian' Principles. Criminal Law and Philosophy 10(3) 427-440.

Loader, I. and Mulcahy, A. (2001) 'The Power of Legitimate Naming' British Fournal of Criminology 41(2) 252-265.

Loader, I. and Sparks, R. (2013) 'Unfinished Business: Legitimacy, Crime Control and Democratic Politics' in J. Tankebe and A. Liebling (eds.). Legitimacy and Criminal Fustice: An International Exploration. (Oxford: Oxford University Press).

Loftus, B. (2008) 'Dominant Culture Interupted: Recognition, Resentment and the Politics of Change in an English Police Force' British Fournal of Criminology 48(6) 756-777

Loftus, B., Goold, B., and Giollabhui, S. (2015) 'From a Visible Spectacle to an Invisible Presence: The Working Culture of Covert Policing' British Fournal of Criminology 56(4) 629-645. 
Lowrey-Kinberg, B. and Buker, S. (2017) “I'm Giving You a Lawful Order”: Dialogic Legitimacy in Sandra Bland's Traffic Stop' Law and Society Review 51(2) 379-412.

Lukes, S. (2005) Power: A Radical View (2nd ed) Palgrave Macmillan.

Mawby, R. (2010) 'Police corporate communications, crime reporting and the shaping of policing news' Policing and Society 20(1) 124-139.

Mazerolle, L., Bennett, S., Davis, J., Sargeant, E., \& Manning, M. (2013). Procedural justice and police legitimacy: a systematic review of the research evidence. Fournal of Experimental Criminology 9 245-274.

McKinnon, A. (2010) 'Elective Affinities of the Protestant Ethic: Weber and the Chemistry' Sociolical Theory 28(1) 108-126

McLaughlin, E. and Murji, K. (1998) 'Resistance through Representation: 'Storylines', Advertising and Police Federation Campaigns' Policing and Society 8(4) 367-399.

Mesko, G. and Tankebe, J. (eds.) (2015) Trust and Legitimacy in Criminal Fustice: European Perspectives (Switzerland: Springer).

Mouzelis, N. (1993) 'The Poverty of Sociological Theory' Sociology 27(4) 675-695.

Mulcahy, A. (1994) 'The Justifications of "Justice": Legal Practitioners' Accounts of Negotiated Case Settlements in Magistrates' Courts' British Fournal of Criminology 34(4) 411-430.

Mulcahy, A. (2006) Policing in Northern Ireland: Conflict, Legitimacy and Reform (Collumpton: Willan Publishing).

Mulcahy, A. and Ellison, G. (2001) 'The language of policing and the struggle for public confidence' Policing and Society 23(2) 10-124.

Madon, N., Murphy, K., \& Sargeant, E. (2017). Promoting police legitimacy among disengaged minority groups: Does procedural justice matter more? Criminology $\mathcal{E}^{\circ}$ Criminal fustice. 17(5) 624-642.

Murray, K. and Harkin, D. (2017) 'Policing in Cool and Hot Climates: Legitimacy, Power and the Rise and Fall of Mass Stop and Search in Scotland' British Fournal of Criminology. 57(4) 885-905.

Neyroud, P. and Sherman, L. (2013) 'Dialogue and Dialectic: Police Legitimacy and the New Professionalism' in J. Tankebe and A. Liebling (eds.). Legitimacy and Criminal fustice: An International Exploration. (Oxford: Oxford University Press).

Owusu-Bempah, A. (2017) 'Race and policing in historical context: Dehumanization and the policing of black people in the 21 $1^{\text {st }}$ century' Theoretical Criminology 21(1) 23-34.

Radburn, M. and Stott, C. (2018) 'The social psychological processes of 'procedural justice': Concepts, critiques and opportunities' Criminology \&̊ Criminal fustice.

Raz, J. (2009) Between Authority and Interpretation: On the Theory of Law and Practical Reason. (Oxford: Oxford University Press). 
Sampson, R.J. and Bartusch, D.J. (1998) 'Legal Cynicism and (Subcultural?) Tolerence of Deviance: The Neighborhood Context of Racial Differences' Law and Society Review $32,4,777-804$.

Sparks, R. (1994) 'Can Prisons Be Legitimate? Penal Politics, Privatization and the Timeliness of an Old Idea' British Fournal of Criminology 34 14-28.

Sunshine, J. and Tyler, T. (2003) 'The role of procedural justice and legitimacy in public support for policing' Law and Society Review 37 513-48.

Tankebe, J. (2014) 'Police Legitmacy' in M. Reisig and R Kane (eds) The Oxford Handbook of Police and Policing (Oxford: Oxford University Press).

Tankebe, J. and Liebling, A. (eds.) (2013) Legitimacy and criminal justice: an international exploration. (Oxford, Oxford University Press).

Tyler, T. (2006) Why People Obey the Law (2nd Ed) (New Haven, CT: Yale University Press).

Tyler. T. and Jackson. J. (2013) 'Future Challenges in the Study of Legitimacy and Criminal Justice' in J. Tankebe and A. Liebling (eds.). Legitimacy and Criminal Fustice: An International Exploration. (Oxford: Oxford University Press).

Walters, G.D. \& Bolger, P.G. (2018) Procedural justice perceptions, legitimacy beliefs, and compliance with the law: a meta-analysis. Fournal of Experimental Criminology Online first.

Wolfe, S.E., Nix, J., Kaminski, R. and Rojek, J. (2016) Is the Effect of Procedural Justice on Police Legitimacy Invariant? Testing the Generality of Procedural Justice and Competing Antecedents of Legitimacy. Foumal of Quantitative Criminology 32: 253282.

Weber, M. (1968) Economy and Society: An Outline of Interpretive Sociology in G. Roth and G. Wittich (eds) (Berkeley and Los Angeles, CA: University of California Press).

Van Hulst, M. (2013) 'Storytelling at the Police Station: The Canteen Culture Revisited' British fournal of Criminology 53 624-642. 